\title{
IMPLEMENTASI METODE BRAINSTORMING DALAM MODEL GROUP INVESTIGATION PADA MATA PELAJARAN EKONOMI UNTUK MENINGKATKAN KEAKTIFAN DAN HASIL BELAJAR SISWA KELAS X IPS 3 SMAN 1 BATU
}

\author{
Yuni Tri Astuti ${ }^{1}$, Agung Haryono ${ }^{2}$ \\ 1. Economic Education Program, Faculty of Economics, State University Malang \\ 2. Economic Education Program, Faculty of Economics, State University Malang \\ yunitriastuti72@gmail.com, Agung.haryono.fe@um.ac.id
}

\begin{abstract}
The purpose of this research is to know the implementation of brainstorming method in group investigation model in Economic subjects and improvement of activity and learning result of students of class X IPS 3 SMAN 1 Batu. Methods of data collection using observation, test questions and field notes and analyzed by qualitative descriptive technique. The result of this research are: (1) improvement of student activity $18,71 \%$ from cycle I to cycle II, that is $63.30 \%$ cycle I and $82.31 \%$ cycle II; (2) the improvement of student learning outcomes is $22.22 \%$ from cycle I to cycle II, which is marked by the increase of $70.37 \%$ complete student in cycle I and increased to $92.59 \%$ cycle II. Implementation of brainstorming method in group investigation model is expected to be used as an alternative model of economical learning that is more innovative to improve student activeness. It is also expected that Economics teachers should implement the implementation of this learning model not only on the discussion of payment system and non-cash payment instruments only, but for other materials that have problems and materials related to the daily life of the students so that students are easier to find the latest information needed to be used as reference material. The results of this study are expected to be used by other researchers as a reference in carrying out the development of similar research. In addition to measuring student activity as well as learning outcomes, other researchers are expected to be able to measure other aspects such as critical thinking skills, communication skills, and so on, so that the results of research become more perfect.
\end{abstract}

Keywords:brainstorming, group investigation, liveliness, learning outcomes

History of Article:

Received : (11 August 2017), Accepted : (19September), Publised:(15 October 1997)

\section{Citation:}

Astuti, Yuni Tri\&Agung Haryono(2017) Implementasi Metode Brainstorming Dalam Model Group Investigation Pada Mata Pelajaran Ekonomi Untuk Meningkatkan Keaktifan Dan Hasil Belajar Siswa Kelas X IPS 3 SMAN 1 Batu [Implementation of Brainstorming Methods In Model Group Investigation In Economic Subjects To Increase Activity And Student Results Class X IPS 3 SMAN 1 Batu]. Jurnal Pendidikan Ekonomi, 10(2), 96-103.

(c) UniversitasNegeri Malang 


\section{PENDAHULUAN}

Ekonomi merupakan mata pelajaran yang wajib diikuti oleh siswa SMA khususnya siswa yang mengambil jurusan IPS. Pembelajaran Ekonomi disekolah seharus-nya mampu mendekatkan konsep yang dipelajari dengan realita yang terjadi dilapangan sehingga menam-bah pemahaman yang mendalam, seperti yang tertera dalam lampiran permendikbud No. 65 tahun 2013 bahwa " proses pembelajaran pada satuan pendidikan seharusnya diselenggarakan secara interaktif, inspiratif, menyenangkan, menantang, memotivasi peserta didik berpartisipasi aktif".

Pada observasi awal ketika mengajar menjadi guru praktikan, kelas X IPS 3 memiliki keaktifan dan hasil belajar rendah dibandingkan kelas lain. Serta terdapat dominasi siswa yang sangat jelas terlihat. Hal tersebut dibuktikan ketika terdapat sesi presentasi dan tanya jawab, beberapa siswa sangat aktif disisi lain terdapat siswa yang sangat pasif, bukti lainnya ketika kegiatan diskusi dan kerja kelompok berlangsung, dalam satu kelompok dapat dilihat mana yang sangat aktif dan yang pasif.Untuk mengatasi permasalahan diatas penulis berusaha memberikan solusi dengan mencoba menerapkan metode serta model pembelajaran yang diharapkan mampu meningkatkan keaktifan serta hasil belajar siswa kelas X IPS 3 SMAN 1 Batu. Salah satu metode yang mampu meningkatkan keaktifan siswa dalam menyampaikan pendapatnya dalah metode brainstorming, menurut Balackova (2004), "Brainstorming, brain writing and mid mapping aregood starting points. They can help to unlock quickly and easily the hidden creative power that all human being process" inti dari metode ini adalah siswa yang menyampaikan pendapatnya tanpa ada yang mengkritik atau menyanggah sebelum sesi evaluasi. Hasil tersebut sesuai dengan penelitian yang dilakukan oleh Wardani (2016), penerapan metode brainstorming dapat meningkatkan aktivitas belajar siswa kelas XI IPS SMA Negeri 1 Sukasada. Sesuai pula dengan hasil penelitian yang dilakukan Setiawan (2016), dimana setelah diterapkannya model pembelajaran Group Investigation, mampu meningkatkan keaktifan peserta didik pada mata pelajaran ekonomi.

Selain penggunaan metode penulis menggunakan model pembelajaran kooperatif Group Investigation, model ini dipakai untuk mengembangkan kreativitas siswa, baik perseorangan maupun kelompok, serta siswa dapat mempersiapkan sendiri materi yang ingin dipelajari, hal tesebut sejalan dengan pendapat Sapir (2013: p. 133) “ pembelajaran kooperatif terbukti lebih unggul dalam meningkatkan hasil belajar siswa dibandingkan dengan model pembelajaran individual yang digunakan selama ini". Penggunaan model pembelajaran Group Investigation mampu meningkatkan hasil belajar, hal sesuai dengan penelitian yang telah dilakukan oleh Rahayuni (2016) bahwa penerapan Penerapan model pembelajaran kooperatif tipe Group Investigation mampu meningkatkan aktivitas dan hasil belajar IPS siswa kelas VII D SMP Negeri 3 Singaraja.

Berdaasarkan uraian diatas, penulis tertarik melakukan penelitian tindakan kelas dengan judul “ Implementasi Metode Brainstorming dalam Model Group Investigation pada Mata Pelajaran Ekonomi Untuk Meningkatkan Keaktifan dan Hasil Belajar Siswa Kelas X IPS 3 SMAN 1 Batu".

\section{METODE PENELITIAN}


Pendekatan dalam penelitian ini adalah pendekatan kualitatifdengan jenis Penelitian Tindakan Kelas (PTK), pelaksaan terdiri dari dua siklus yang masingmasing siklus terdiri dari 3 kali pertemuan. Kehadiran penulis dalam penelitian yaitu sebgai pengajar sekaligus perencana, pelaksana, pengumpul dta, serta melaporkan hasil penelitian.

Penelitian ini dilakukan di kelas X IPS 3 SMAN 1 Batu yang beralamat di Jl. K.H Agus Salim 57 Kota Batu. Subjek penelitian dalam penlitian ini dalah siswa kelas X IPS 3 SMAN 1 Batu yang berjumlah 27 Siswa, 20 siswa perempuan dan 7 siswa laki-laki. Pengumpulan data dalam penelitian ini yaitu menggunakan observasi, soal tes serta catatan lapangan. Teknik pengumpulan data menggunakan observasi yang digunakan untuk mengetahui kegiatan penulis dalam menerapkan implementasi metode brainstorming dalam model group investigation serta keaktifan siswa. Pengamatan dilakukan ketika proses pembelajaran berlangsung. Untuk melaksanakan observasi kegiatas guru dalam penerapan model penulis dibantu oleh 3 observer yaitu 2 teman sejawat dan 1 guru bidang study Ekonomi dengan menggunakan lembar observasi, sedangkan untuk mengetahui keaktifan siswa dilakukan juga oleh ketiga observasi menggunakan lembar observasi keaktifan siswa. Tes yang digunakan dalam penelitian ini berupa pre test dan post test bejenis pilihan ganda yang diadakan setiap siklus. Tes ini digunakan untuk mengukur tingkat pemahaman siswa terhadap materi yang diajarkan. Soal tes diujikan terlebih dahulu untuk mengetahui validitas, reliabilitasnya, soal tes ini diujikanpada kelas XI IPS 3 SMAN 1 Batu yang berjumlah 30 siswa, sedangkan untuk menghitung validitas dan reliabilitasnya menggunakan SPSS 21.0 for windows. Catatan lapangan digunakan untuk mengumpulkan data-data yang berkaitan dengan kegiatan belajar mengajar yang meliputi keterangan siswa yang hadir, siswa yang gaduh dll, dalam pembelajaran dikelas.

Analisis Data

1. Pengelolaan Observasi Tindakan Guru

Pengelolaan data dilakukan dengan analisis deskriptif, dimana data yang diperoleh kemudian dihitung berdasarkan rusmus presentase keberhasilan tindakan guru.

2. Pengelolaan Data Observasi Keaktifan Siswa

Untuk melihat presentase keaktifan siswa selama proses pembelajaran berlangsung dengan menggunakan rumus yang kemudian dianalisis dengan langkah-langkah sebagai berikut:

a. Menilai keaktifan setiap siswa dengan mengacu pada kriteria pada sariap indikator.

b. Merata-rata nilai keaktifan seluruh siswa.

c. Membandingkan secara klasikal keaktifan siswa pada sisklus I dan siklus II.

d. Mendiskripsikan dengan kalimat untuk menjelaskan terjadi peningkatan atau tidak.

3. Hasil Belajar Siswa

Penilaian hasil belajar siswa dilakukan dengan langkah-langkah sebagai berikut:

a. Memberikan pre test kepada siswa sebelum proses pembelajaran untuk mengukur kemampuan siswa terhadap materi yang dipelajari dan memberikan post test kepada siswa sesudah proses pembelajaran. 
b. Memberikan nilai kepada masing-masing siswa sesuai dengan kemampuannya.

c. Merata-rata nilai pre test dan post test seluruh siswa.

d. Membandingkan hasil belajar siswa pada aspek kognitif pada siklus I dan II apakah terjadi peningkatan atau tidak.

e. Mendiskripsikan dengan kalimat untuk menjelaskan peningkatan pada aspek kognitif dari setiap siklus.

\section{HASIL DAN PEMBAHASAN}

Pelakasanaan Tindakan Kelas dengan implementasi metode brain-storming dalam model group investigation disetiap siklus mencangkup perencanaan, pelaksanaan, penga-matan, dan refleksi.

Tabel 1 Perbandingan Persentase Keberhasilan Tindakan Guru Siklus I dan II

\begin{tabular}{cccccc}
\hline Jml & \multicolumn{5}{l}{ Rata-rata Tingkat Ketercapaian Pelaksanaan Tindakan } \\
& Siklus I & Kate-gori & Siklus II & Kate-gori & Pening-katan \\
& & & & & \\
\hline $\mathbf{3}$ & $73.68 \%$ & Baik & $83.33 \%$ & Sangat Baik & $9.65 \%$ \\
\hline
\end{tabular}

Dari tabel diatas dapat dilihat terjadi kenaikan keberhasilan guru sebesar $9.65 \%$ dari siklus I ke siklus II.

\section{Tabel 2 Perbandingan Rata-Rata Hasil Observasi Keaktifan Siswa Siklus I} dan Siklus II

\begin{tabular}{lllll}
\hline \multicolumn{2}{l}{ Rata-Rata Tingkat Keaktifan Siswa } \\
\multicolumn{1}{l}{} \\
\hline Siklus I & Kate-gori & Siklus II & Kategori & Pening-katan \\
\hline $\mathbf{6 3 . 6 0 \%}$ & Cukup Aktif & $82.31 \%$ & Aktif & $18.71 \%$ \\
\hline
\end{tabular}

Dari tabel diatas dapat dilihat terjadi kenaikan keaktifan siswa dari siklus I ke siklus II sebesar $18.71 \%$. Dengan demikian dapat disimpulkan bahwa penggunaan implementasi metode brainstorming dalam model group investigation mampu meningkatkan keaktifan siswa ketika proses pembelajaran

Tabel 3 Perbandingan Ketuntasan Belajar Siswa Ranah Kognitif Siklus I dan Siklus II

\begin{tabular}{|c|c|c|c|c|}
\hline \multicolumn{5}{|c|}{ Rata-Rata Peningkatan Hasil Belajar Siswa Ranah Kognitif } \\
\hline Siklus I & kategori & Siklus II & Kategori & Pening-katan \\
\hline 69.63 & Baik & & Sangat Baik & 10.37 \\
\hline
\end{tabular}

Dari tabel diatas dapat disimpulkan bahwa ketuntasan belajar siswa mengalami peningkatan pada satiap siklusnya.

\section{Implementasi Metode Brains-torming dalam Model Group Inves-tigation Pada Mata Pelajaran Ekonomi Kelas X IPS 3 SMAN 1 Batu}


Penerapan implementasi metode Brainstorming dalam model Group Investingation pada siklus I belum dapat terlaksana dengan maksimal, Meskipun masih banyak kekurangan namun pada siklus satu siswa sudah mampu mengeluarkan ide, pendapatnya, serta menanggapi masalah yang didapat kelompok masing-masing tanpa ada yang mengkritik, baik dari guru maupun anggota lain sebelum sesi evaluasi. Hal ini sesuai dengan pendapat Balackova (2004) bahwa pada sesi brainstormingtidak ada kritik atau penilaian. Ide orang lain atau ide kita sendiri tidak boleh dikritik meskipun tampak aneh atau bodoh. Karena penilaian akan menghentikan proses kreatif serta menyebabkan ketegangan dalam kelompok. Pada siklus II, pembelajaran berjalan dengan lancar, baik siswa secara individu maupun kelompok, hal ini ditunjukan setiap siswa punya kontribusi dalam kelompoknya, masing-masing kelompok memperoleh banyak ide yang diperoleh dari setiap anggota. Hal tersebut sesuai dengan teori yang dikemukakan Rawlinson (1971: p.72), bahwa Brainstorming suatu cara untuk medapat banyak ide dalam waktu yang sangat singkat. Selain itu penggunaan model pembelajaran Group Investigation membantu siswa lebih kompak dalam menyelesaikan tugas, tidak ada dominasi salah satu anggota ataupun anggota kelompok yang tidak mempunyai fungsi lagi, hal tersebut sesuai dengan teori yang dikemukakan oleh Sumarmi (2012: p.127) model pembelajaran Group Investigation memungkinkan peserta didik menjadi lebih aktif terlibat dalam belajar, baik secara mandiri atau dalam kelompok diskusi. Pada saat presentasipun siswa terlihat percaya diri, baik dalam menjawab pertanyaan dari kelompok lain maupun dari guru, hal ini karena pada saat melakukan investigasi masalah, semua siswa didorong dalam keterlibatan belajar, baik ketika mengidentifikasi topik bahasan yang mereka peroleh, merencanakan apa yang diinvestigasi sampai dengan penyajian laporan akhir sehingga mereka sudah paham dengan materi yang dibahas, hal ini sesuai dengan teori yang dikemukakan oleh Sharan dan Sharan (1990) model Group Investigasi para siswa bekerja melalui enam tahap, yaitu mengidentifikasi topik yang akan diselidiki, merencanakan investigasi yang akan diselidiki, melakukan investigasi, menyiapkan laporan akhir, penyajian laporan akhir serta evaluasi.

\section{Implemenentasi Metode Brain-storming Dalam Model Group Investigation Dapat Meningkatkan Keaktifan Siswa Pada Mata Pelajaran Ekonomi kelas X IPS 3 SMAN 1 Batu}

Penerapan implementasi metode brainstorming dalam model group investigation pada mata pelajaran ekonomi kelas X IPS 3 SMAN 1 Batu terbukti dapat meningkatkan keaktifan peserta didik. Hal ini dibuktikan oleh tingginya skor pencapaian siswa pada lima indikator keaktifan saat pelaksanaan pembelajaran. Lima indikator keaktifan siswa adalah antusiasme bertanya, menjawab, mendengarkan, serta kerja sama, Berjalannya aktivitas-aktivitas siswa diatas sejalan dengan teori yang dikemukakan Paul B.Dierich (dalam Sardiman, 2007: p.101) mengenai macam-macam aktivitas siswa.

Dari beberapa macam aktivitas yang dilakukan siswa dapat terlihat bahwasannya pembelajaran melibatkan siswa secara langsung, seperti halnya terlibat dalam memecahkan masalah, bertanya kepada guru mapun siswa lain mengenai hal yang kurang dipahami, setiap kelompok mencari berbagai informasi yang ingin mereka ketahui, serta menggunakan informasi yang mereka peroleh tadi 
untuk menjawab permasalahan yang dihadapi, selain itu siswa juga sangat patuh mengikuti setiap intruksi guru. Hal tersebut sesuai dengan teori yang dikemukakan Sudjana (2010: p.61), bahwa keaktifan dapat dilihat dari beberapa hal. Hasil tersebut sesuai dengan penelitian yang dilakukan oleh Wardani (2016), penerapan metode brainstorming dapat meningkatkan aktivitas belajar siswa kelas XI IPS SMA Negeri 1 Sukasada

\section{Implementasi Metode Brain-storming Dalam Model Group Investigation Dapat Meningkatkan Hasil Belajar Siswa Terhadap Mata Pelajaran Ekonomi Kelas X IPS 3 SMAN 1 Batu}

Berdasarkan analisis hasil belajar siswa kelas X IPS 3 SMAN 1 Batu yang terdiri dari nilai post test setiap akhir siklus, pelaksanaan implementasi metode brainstorming dalam model group investigation mengalami peningkatan dari siklus I ke siklus II. Peningkatan hasil belajar pada siklus II ini disebabkan siswa sudah paham dengan apa yang harus dikerjakan saat pembelajaran berlangsung, serta antara guru dan siswa mampu bekerjasama dengan baik dan tidak ada dominasi lagi dalam setiap kelompok. Setiap anggota mempunyai kontribusi masing-masing dalam penyelesaian tugasnya. Dengan meningkatnya hasil belajar siswa pada siklus II dapat dikatakan siswa telah paham dengan materi yang diajarkan dengan penerapan implementasi metode brainstorming dalam model group investigation berdasakan tujuan pembelajaran yang dirumuskan. Menurut Romadoni (2014) Indikator yang dijadikan sebagai tolak ukur dalam menyatakan bahwa proses belajar mengajar dikatakan berhasil adalah tercapainya tujuan dalam belajar yaitu ditunjukkan dengan kemampuan siswa dalam mencapai prestasi belajar secara maksimal. Hal ini sejalan dengan pendapat (Purwanto, 2009: p.44) bahwa hasil belajar seringkali digunakan sebagai ukuran untuk mengetahui seberapa jauh seseorang menguasai bahan yang sudah diajarkan. Selain itu penggunaan implementasi metode brainstorming dalam model group investigation dirasa cukup efektif digunakan untuk meningkatkan pemahaman siswa terhadap materi pelajaran. Hal tersebut sesuai dengan pendapat Slameto (2010: p.65) guru yang progresif berani mencoba metode-metode baru, yang dapat membantu meningkatkan kegiatan belajar mengajar, dan meningkatkan motivasi siswa untuk belajar. Peningkatan hasil belajar siswa ini sesuai dengan penelitian yang dilakukan oleh Alfianita dkk (2014) yang menyatakan bahwa metode brainstorming yang dilakukan di MAN 2 Jember mampu meningkatkan kreativitas serta hasil belajar siswa pada mata pelajaran Sejarah.

\section{KESIMPULAN}

Kesimpulan dari penelitian ini, adalah sebagai berikut: 1) Penerapan implementasi metode brainstorming dalam model group investigation pada mata pelajaran Ekonomi kelas X IPS 3 SMAN 1 Batu terlaksana dengan sangat baik. Pada siklus I tingkat ketercapaian tindakan masuk kategori baik, disiklus II tingkat ketercapaian tindakan mengalami kenaikan masuk kategori sangat baik. 2) Penerapan implementasi metode brainstorming dalam model group investigation dapat meningkatkan keaktifan siswa pada mata pelajaran ekonomi kelas X IPS 3 SMAN 1 Batu. Hal ini dibuktikan oleh persen-tase rata-rata hasil pengamatan terhadap keaktifan siswa pada siklus I masuk pada kategori cukup aktif meningkat di siklus II yang masuk kategori Aktif; 2) Penerapan implementasi metode Brainstorming 
dalam model group Investigation dapat meningkatkan hasil belajar siswa pada mata pelajaran ekonomi kelas X IPS 3 SMAN 1 Batu. Hal ini dilihat dari rata-rata hasil post test siswa siklus I sebesar 69.63 meningkat 10.37 di siklus II menjadi 80. Pada siklus I presentase siswa yang belum tuntas adalah $29.63 \%$ (8 orang) sedangkan siswa yang tuntas $70.37 \%$ (19 orang) disiklus II siswa yang belum tuntas $7.41 \%$ (2 orang ) sedangkan siswa yang tuntas meningkat menjadi $92.59 \%$ (25 orang).

Berdasarkan pemaparan kesimpulan di atas, saran dari penulis adalah sebagai berikut: 1) Implementasi metode brainstorming dalam model group investigation diharapkan dapat digunakan sebagai alternatif model pembelajaran ekonomi yang lebih inovatif untuk meningkatkan keaktifan siswa. Diharapkan pula bagi guru Ekonomi sebaiknya menerapkan implementasi model pembelajaran ini tidak hanya pada pembahasan materi system pembayaran dan alat pembayaran tunai non tunai saja, akan tetapi untuk materi lain yang memiliki permasalahan dan materi yang berhubungan kehidupan sehari-hari siswa sehingga siswa lebih mudah mencari informasi terbaru yang dibutuhkan untuk dijadikan bahan referensi. 2) Hasil penelitian ini diharapkan dapat digunakan oleh peneliti lain sebagai acuan dalam melaksanakan pengembangan penelitian yang serupa. Selain mengukur keaktifan siswa serta hasil belajar, diharapkan peneliti lain dapat mengukur aspek-aspek lain seperti kemampuan berpikir kritis, kemampuan berkomunikasi, dan sebagainya, sehingga hasil penelitian menjadi lebih sempurna.

\section{DAFTAR RUJUKAN}

Alfianita, Nurul dkk. (2014) Penerapan Metode Pembelajaran Brainstorming Untuk Meningkatkan Kreativitas dan Hasil Belajar Sejarah Peserta Didik Kelas XH MAN 2 Jember Tahun Ajaran 2013/2014. Unej Jurnal Pendidikan, 1(1), 1-7, (Online), (http://repository.unej.ac.id/bitstream/handle/123456789/63048/ALFIANI TA\%20IMANSARI.pdf;sequence=1), diakses 15 Maret 2017

Balackova, H. (2004) Brainstorming: a creative problem-solving method. (Online),(http://www.unido.org/fileadmin/import/16953_Brainstorming.pdf) , diakses pada 15 Oktober 2016

Depdikbud (2013) Permendikbud No 65 Tahun 2013 tentang standar proses Purwanto (2009) Evaluasi Hasi Belajar. Yogyakarta : Pustaka Belajar Rawlinson. J.G. (1971) Berfikir kreatif dan Brainstorming. Terjemahan Marbun B.N \& Wachid D. 1986. Jakarta : Erlangga

Rahayuni, Kadek M. (2016). Penerapan Model Pembelajaran Kooperatif Tipe Group Investigation Untuk Meningkatkan Aktivitas dan HasilBelajar IPS Siswa Kelas VIII D SMP Negeri 3 SingarajaTahun Pelajaran 2015/2016. Jurnal Program Studi Pendidikan Ekonomi, 7 (2). (Online), (https://scholar.google.co.id/scholar?q=metode+brainstorming\%2C+vol\&h l=id\&as_sdt=0\%2C5\&oq=brainstorming), Diakses 10 Maret 2017.

Romadoni, S. (2014) Efektivitas Penerapan Metode Brainstorming Terhadap Peningkatan Minat dan Prestasi Belajar Ekonomi Siswa Kelas X SMK YPKK 3 Sleman. Jurnal Skripsi. Yogyakarta: FE UNY. 
Sapir (2013) Perencanaan Pembelajaran Ekonomi. Malang: FE UM.

Sardiman, A.M (2007) Interaksi dan Motivasi Belajar Mengajar. Jakarta: PT.RajaGrafindo Persada.

Sharan, Yael \& Slhomo, (1990) Group Investigation expands Cooperatif Learning.Online,(https://www.researchgate.net/publication/234687465), diakses tanggal 4 Februari 2017

Setiawan (2016) Penerapan model pembelajaran kooperatif tipe Group Investigation untuk meningkatkan hasil belajar dan keaktifan peserta didik pada mata pelajaran ekonomi di kelas X 6K2 SMAN 10 Malang. Universitas Negeri Malang : Jurnal Skripsi Tidak Diterbitkan.

Slameto (2010) Belajar dan Faktor-Faktor yang Mempengaruhinya. Jakarta : Rineka Cipta.

Sudjana, Nana (2010) Penilaian Hasil ProsesBelajar Mengajar. Bandung: Remaja Rosdakarya.

Sumarmi (2012) Model-model Pembelajaran Geografi. Malang. Aditya Media Publising.

Wardani, N.T. (2016) Penerapan Metode Brainstorming dalam Rangka Peningkatan Aktivitas dan Hasil Belajar Pada Mata Pelajaran Ekonomi Siswa Kelas XI IPS 1 SMA Negeri 1 Sukasada Tahun Ajaran 2016/2017. Jurnal Program Studi Pendidikan Ekonomi, 8 (3). (Online), (http://ejournal.undiksha.ac.id/index.php/JJPE/article/viewFile/7796/5326) , Diakses 10 Maret 2017. 